\title{
Librarians as Teachers: A Qualitative Inquiry into Professional Identity
}

\section{Scott Walter}

This study explores the development of "teacher identity" among academic librarians through a series of semistructured interviews. Drawing both on the idea of teacher identity from the literature of teacher education and on existing studies of professional stereotypes and professional identity development among academic librarians, this study explores the degree to which academic librarians think of themselves as teachers, the ways in which teaching has become a feature of their professional identity, and the factors that may influence academic librarians to adopt a "teacher identity" as part of their personal understandings of their role on campus.

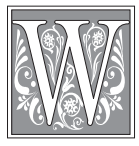

hen did you decide to stop being a teacher?" The question came to me during a job interview; it struck me as strange. At the time it was asked, I had just completed a one-hour presentation on the evolution of "open access" publishing and its potential impact on accepted models of scholarly communication. The presentation included clear statements regarding learning objectives, opportunities for active learning through discussion, and a brief assessment of what had been learned through a question-and-answer session at the end of the hour. My "students" that day were potential colleagues at a research library whose staff I was hoping to join. Their questions during the presentation had been thoughtful and the comments made as they exited the room complimentary. When did I decide to stop being a teacher? Hadn't I just been teaching a few minutes ago?

What makes a teacher? Does holding an appropriate credential make someone a teacher, or does professional identity as a teacher grow out of a regular responsibility for teaching? Does saying that one is a teacher refer to one's mastery of an identifiable set of pedagogical skills, or, rather, to the way in which one approaches one's work (in a classroom or outside of one)? These questions are of obvious interest to preservice teachers and teacher educators and have been the subject of a number of studies of "teacher identity" over the past 15 years. What is their significance for librarians?

Librarianship is a profession in transition, and this is especially true in the case of academic librarians. ${ }^{1}$ Changes in scholarly communication, advances in information technology, and new models for professional staffing of academic libraries all present challenges to academic librarians and to the administrators who strive to integrate library services into the broader mission(s) of the college or university. As important as any of these issues is the fact that academic librarians

Scott Walter is Associate University Librarian for Services and Associate Dean of Libraries and Professor of Library Administration at the University of Illinois at Urbana-Champaign; e-mail: swalter@uiuc.edu. 


\begin{tabular}{|l|r|r|r|r|}
\hline \multicolumn{7}{|c|}{ TABLE 1 } \\
Information Literacy Instruction at the \\
University of Maryland \\
\hline \hline Year & $\begin{array}{r}\text { Classes } \\
\text { Taught }\end{array}$ & \multicolumn{1}{|c|}{$\Delta$} & $\begin{array}{c}\text { Students } \\
\text { Taught }\end{array}$ & \multicolumn{1}{c|}{$\Delta$} \\
\hline $1994-1995$ & 661 & $*$ & 13,244 & $*$ \\
\hline $1995-1996$ & 626 & $-5.3 \%$ & 12,003 & $-9.4 \%$ \\
\hline $1996-1997$ & 736 & $+17.6 \%$ & 13,951 & $+16.2 \%$ \\
\hline $1997-1998$ & 723 & $-1.8 \%$ & 12,629 & $-9.5 \%$ \\
\hline $1998-1999$ & 759 & $+5 \%$ & 12,711 & $+.6 \%$ \\
\hline $1999-2000$ & 855 & $+12.6 \%$ & 15,767 & $+24 \%$ \\
\hline $2000-2001$ & 968 & $+13.2 \%$ & 18,836 & $+19.5 \%$ \\
\hline $2001-2002$ & 1,008 & $+4.1 \%$ & 21,075 & $+11.9 \%$ \\
\hline $2002-2003$ & 1,166 & $+15.7 \%$ & 19,172 & $-9 \%$ \\
\hline $2003-2004$ & 1,090 & $-6.5 \%$ & 21,980 & $+14.6 \%$ \\
\hline $\mathbf{1 9 9 4 - 2 0 0 4}$ & & $+\mathbf{6 4 . 9 \%}$ & & $+\mathbf{6 6 \%}$ \\
\hline
\end{tabular}

about the complexity of the instructional work required of librarians in this environment (e.g., the difference between preparing for a class that consists of a library tour versus one that involves the development of an assignment measuring student ability to apply critical thinking to the selection of information resources that will be included in the final course grade), but they demonstrate that, at the most basic level, the amount of professional time and effort dedicated to teaching in academic libraries has increased significantly over the past decade.

Given this trend, it is no

are increasingly responsible for a variety of activities directly related to teaching and learning, and that the scope of those responsibilities has expanded in recent years to encompass instruction delivered in the library, across the campus, and in online learning environments. ${ }^{2}$

Academic librarians have been responsible for direct instruction of students for well over a century, but changes to the academic curriculum, the demographics of the college student body, and the place of information technology (especially the World Wide Web) in higher education have all contributed to an increasing focus on the role of the librarian as teacher over the past 30 years. ${ }^{3}$ Consider as representative examples from the research library environment the recent growth of the library instruction programs at the University of Maryland, the University of Kansas, and Washington State University: ${ }^{4}$

Admittedly, these numbers are crude and tell us nothing

\begin{tabular}{|l|r|r|r|r|}
\hline \multicolumn{7}{|c|}{ TABLE 2} \\
Information Literacy Instruction at the \\
University of Kansas \\
\hline Year & $\begin{array}{r}\text { Classes } \\
\text { Taught }\end{array}$ & $\Delta$ & $\begin{array}{c}\text { Students } \\
\text { Taught }\end{array}$ & $\Delta$ \\
\hline $1994-1995$ & $\mathrm{n} / \mathrm{a}$ & $*$ & $\mathrm{n} / \mathrm{a}$ & $*$ \\
\hline $1995-1996$ & $\mathrm{n} / \mathrm{a}$ & $*$ & $\mathrm{n} / \mathrm{a}$ & $*$ \\
\hline $1996-1997$ & $\mathrm{n} / \mathrm{a}$ & $*$ & $\mathrm{n} / \mathrm{a}$ & $*$ \\
\hline $1997-1998$ & $\mathrm{n} / \mathrm{a}$ & $*$ & $\mathrm{n} / \mathrm{a}$ & $*$ \\
\hline $1998-1999$ & 776 & $*$ & 9,025 & $*$ \\
\hline $1999-2000$ & 697 & $-10.2 \%$ & 9,540 & $+5.7 \%$ \\
\hline $2000-2001$ & 759 & $+8.9 \%$ & 10,918 & $+14.4 \%$ \\
\hline $2001-2002$ & 712 & $-6.2 \%$ & 11,820 & $+8.3 \%$ \\
\hline $2002-2003$ & 751 & $+5.5 \%$ & 13,161 & $+11.3 \%$ \\
\hline $2003-2004$ & 878 & $+16.9 \%$ & 16,556 & $+25.8 \%$ \\
\hline $\mathbf{1 9 9 8}-\mathbf{2 0 0 4}$ & & $+\mathbf{1 3 . 1} \%$ & & $+\mathbf{8 3 . 4} \%$ \\
\hline
\end{tabular}
surprise to find that analyses of the professional responsibilities enumerated as part of advertisements for academic library positions in outlets such as American Libraries, College \& Research Libraries News, and the Chronicle of Higher Education during this time show that a commitment to providing direct instruction to faculty, staff, or students is an increasingly 
A Qualitative Inquiry into Professional Identity 53

common requirement for appointment. ${ }^{5}$ At least one study has suggested that the ability to demonstrate one's teaching skills can improve one's chances of obtaining a position in a competitive professional market, and others have shown that there is a strong interest among many libraries in the formal evaluation of instruction provided by librarians. ${ }^{6}$ Even work outside the classroom - for example, service on the reference desk, participation in scholarly communications initiatives - has increasingly been cast within the context of the librarian's role as teacher. ${ }^{7}$ Teaching skills are clearly recognized as important to the professional work of academic librarians, but to what degree do academic librarians think of themselves as teachers when they consider their place on campus, and to what degree is "teacher identity" a recognized aspect of the broader professional identity of academic librarians?

Drawing on the literature of professional education and professional identity among academic librarians as well as the literature of teacher education, this study will explore the ways in which academic librarians are introduced to teaching as part of their professional work, the degree to which academic librarians think of themselves as teachers, the ways in which being a teacher has become a significant feature of their professional identity, and the factors that may influence an academic librarian to adopt a "teacher identity" as part of his or her understanding of the librarian's role on campus.

\section{Methodology}

Considerable research has been conducted over the past 30 years on the education of instruction librarians and the ways in which librarians with a responsibility for teaching go about improving their peda-
TABLE 3

racy Instruction at Washington State University

\begin{tabular}{r|r|r|r|} 
Casses & \multicolumn{1}{|c|}{$\Delta$} & $\begin{array}{c}\text { Students } \\
\text { Taught }\end{array}$ & \multicolumn{1}{c|}{$\Delta$} \\
\hline 411 & $*$ & 5,951 & $*$ \\
\hline 355 & $-13.6 \%$ & 6,232 & $+4.7 \%$ \\
\hline 372 & $+4.8 \%$ & 7,439 & $+19.4 \%$ \\
\hline 516 & $+38.7 \%$ & 9,396 & $+26.3 \%$ \\
\hline 578 & $+12 \%$ & 9,866 & $+5 \%$ \\
\hline 616 & $+6.6 \%$ & 15,863 & $+60.8 \%$ \\
\hline 684 & $+11 \%$ & 11,364 & $-28.4 \%$ \\
\hline 715 & $+4.5 \%$ & 11,301 & $-.6 \%$ \\
\hline 934 & $+30.6 \%$ & 13,548 & $+19.9 \%$ \\
\hline 881 & $-5.7 \%$ & 13,495 & $-.4 \%$ \\
\hline & $+\mathbf{1 1 4 . 4 \%}$ & & $+\mathbf{1 2 6 . 8 \%}$ \\
\hline
\end{tabular}

gogical skills. For the most part, these studies made use of quantitative research methods, especially survey method. Scott B. Mandernack, for example, surveyed librarians in Wisconsin to determine the scope of their instructional responsibilities, the ways in which they had been prepared to meet those responsibilities, and their preferences in terms of continuing education opportunities in the field of instruction. ${ }^{8}$ Charles D. Patterson and Donna W. Howell reported the results of a national survey of instruction librarians that gathered information on professional responsibilities, previous teaching experience, and job satisfaction. ${ }^{9}$ Rebecca Albrecht and Sara Baron, Mary Ellen Larson and Ellen Meltzer, and Brigit Shea Sullivan are among several who have surveyed professional education programs to determine the availability of formal coursework on instruction for preservice librarians. ${ }^{10}$ Diana Shonrock and Craig Mulder used a national survey to identify core competencies for instruction librarians, as well as to identify the ways in which librarians preferred to pursue continuing education to meet those competencies. ${ }^{11}$ Finally, Rebecca Albrecht, Sara Baron, and Elizabeth Blakesley 
Lindsay used electronic discussion lists to survey instruction librarians on issues such as how preservice and continuing professional education opportunities helped prepare them for different aspects of their instructional work, the percentage of their professional time now dedicated to that work, and the challenges facing instruction librarians in the contemporary library environment. ${ }^{12}$ Rather than draw on the quantitative tradition, however, this study will follow the example set by earlier research on professional identity among teachers and librarians and rely on qualitative research methods. ${ }^{13}$

Qualitative research methods-case study, interviewing, focus group analysis, and ethnography - are a relatively recent addition to the library literature, but they have quickly become popular among scholars and practitioners in library and information science. ${ }^{14}$ Because qualitative inquiry is well suited to elicit a range of responses on topics related to personal perceptions, personal motivation, and cultural and contextual factors that may influence library use, a number of studies have been completed over the past 15 years that apply one or more of these methods to questions related to the use of electronic resources, user informationseeking behaviors, user satisfaction with library services, and assessment of library services. ${ }^{15}$ Administrative decision-making, too, has benefited from the increased availability of qualitative data regarding, for example, perceptions of service quality and usability of Web sites. ${ }^{16}$ Finally, qualitative inquiry has proven useful for the study of instructional services in academic libraries, with Christine Bruce, Kate Manuel et al., and Nan Seamans all employing qualitative methods to explore perceptions of information literacy and attitudes toward information literacy instruction among college students and faculty. ${ }^{17}$ Qualitative research methods are defined by a number of features that are often contrasted with those defining quantitative approaches such as survey research, but the most significant for this study are their focus on descriptive data and emergent research design. ${ }^{18}$

Unlike earlier studies of the education of instruction librarians, this study will not rely on data collected from a randomly selected group of practitioners using a carefully prepared instrument. Qualitative inquiry "deals with data that are in the form of words, rather than numbers and statistics," and on developing an interpretation of that data that explores the meaning for participants of the experiences under study..$^{19}$ Rather than focusing on quantifiable data such as the number of professional education programs for librarians that provide access to formal coursework in the field of instruction or prevailing opinion regarding the most important professional skills for teaching librarians, this study will focus on the lived experience of practicing librarians to explore their work as teachers. Equally exploratory is the research design, which, consistent with good practice in qualitative inquiry, emerged from the experience of the interviewing process and was shaped in large part by that process. Like many qualitative research studies, the pool of participants for the current study was small $(n=6)$ when compared with those brought together for quantitative analysis. But, while the limited sample size may mean that any conclusions drawn from this study will be preliminary in nature, even initial conclusions may suggest a new area of inquiry for those who are interested in promoting the instructional role of the academic librarian as part of ongoing discussions about the future of the profession.

\section{Review of the Literature}

Because qualitative research is almost always exploratory in nature, it is not uncommon to find that the context for a given study within the literature may be ill defined. ${ }^{20}$ A number of studies relevant to the education of instruction librarians have been noted above, but these are of limited importance to a study of profes- 
sional identity among instruction librarians (for reasons that will be discussed below). More important are the studies drawn from the literature of teacher education that provide an interpretive framework that suggests a broader set of questions relevant to the work of librarians as teachers. Among teacher educators, this framework is referred to as "learning to teach." ${ }^{21}$

\section{Teacher Identity and Learning to Teach}

"There is a distinction," wrote Deborah Britzman in her seminal ethnographic study of student teachers, "between learning to teach and becoming a teacher." 22 Discussions of learning to teach often focus on mastery of pedagogical skills, instructional design, classroom management, and strategies for the assessment of student learning. While each of these is important, it is equally important to consider how one makes a commitment to one's professional identity as a teacher. Professional skills and professional identity, she argues, are complementary aspects of a holistic approach to teacher education. While each aspect is critical to the development of the student teacher as professional, the focus in teacher education programs has historically been on the development of competencies and skills, and limited attention has been paid to issues of professional identity development. ${ }^{23}$

Over the past 15 years, a number of studies have challenged this traditional model of teacher education by exploring the ways in which students are socialized into their professional identity as teachers. ${ }^{24}$ Many of these studies explore the need to focus overt attention on the articulation and development of professional identity as part of preservice teacher education, but others suggest the importance of continued attention to professional identity development among experienced practitioners. ${ }^{25}$ Common to all of these studies is an appreciation of how important it is to foster the emergence, development, and promotion of "teacher identity" as an integral part of preservice and continuing professional education for teachers.

Teacher identity may be defined as "the way in which individuals think about themselves as teachers." ${ }^{26}$ How one thinks of oneself as a teacher can affect everything from successful induction into the profession to effectiveness in the classroom to the ability to cope with change and to implement new practices in one's instructional work. ${ }^{27}$ Renewing one's commitment to one's teacher identity (or embracing a new one) can be critical to ongoing growth as a professional. ${ }^{28}$ With this in mind, teacher educators have suggested that direct attention to the development of professional identity is critical to the success of both preservice professional education programs and in-service and continuing education opportunities.

As important as the definition of teacher identity as a subject both of scholarly inquiry and practice in teacher education classrooms is the exploration of the factors outside of formal educational opportunities that shape the development of one's professional identity as a teacher. Sociologist Dan Lortie referred to early exposure to various models of teacher identity as an "apprenticeship of observation." ${ }^{29}$ Quite simply, children, adolescents, and young adults (both in high school and in college) have greater exposure to the profession of teaching through their experience as students than they do to any other single profession; that is, they learn what (they believe) it means to be a teacher through direct observation of professionals at work. J. Gary Knowles expands on this idea to conclude that there are three primary influences on a preservice teacher's image of himself or herself as a professional: (1) experiences with teachers from childhood and adolescence; (2) previous professional role models; and (3) prior teaching experience. ${ }^{30}$ Other scholars in the field of teacher education add contextual factors to the biographical influences identified by Knowles, including the community of peers with whom 
one interacts on a regular basis and the disciplinary community that one joins as a teacher (for example, of chemistry, history, or mathematics). ${ }^{31}$ Exposure to standard bodies of knowledge, statements of professional ethics, and the organizational structure of schooling in America are all important aspects of professional education for teachers, these authors argue, but equally important are the life experiences through which one comes to know what it means to be a teacher.

\section{Librarians Learning to Teach}

Librarians, like teachers, are introduced to a well-defined body of professional knowledge and skills as part of their preservice education. Typically, this might include an introduction to print and electronic reference sources, cataloging and classification systems, basic strategies for information retrieval, and management of library services. This outline is incomplete as there is no national standard for required coursework in the field of library and information science (LIS) education. Moreover, recent years have seen emergent topics such as information architecture, human-computer interaction, and digital content development replace traditional courses in indexing or cataloging as part of the preservice librarian's program of study. But, while librarians (especially academic librarians) find themselves increasingly called upon to act (and to think of themselves) as teachers, few are provided with any training in how to teach as part of their professional education.

This lacuna in LIS education has been repeatedly noted in a series of studies conducted over the past 25 years and, were it the goal of the present study to corroborate those findings, we would doubtless find that the place of teacher training as part of the professional education for preservice librarians remains marginal. ${ }^{32}$ But, is the question of the availability of coursework in the field of instruction still the one most worthy of study, or does the framework for inquiry suggested by research on "learning to teach" provide us with a new set of questions about the ways in which academic librarians are (or are not) prepared for their work as teachers?

What do we know about the scope and content of the information literacy and instruction courses currently offered in LIS programs? As important, given what the studies cited above tell us about the limited availability of such courses, what do we know about the life experiences through which the vast majority of academic librarians have been introduced to their role as teachers? To provide a foundation for exploring these questions, we must first review what is already known about librarians learning to teach.

Research into the professional education offered to librarians who find themselves required to teach as a regular part of their work has been largely concerned with three questions:

- To what degree is academic coursework focused on instruction available to preservice librarians as part of their professional education?

- In the absence of such coursework, what other avenues have librarians pursued to become proficient in their instructional responsibilities?

- What are the core competencies that should be mastered by a librarian interested in being an effective teacher?

A comprehensive review of this literature is impossible in an essay of this length, but those interested in complementary reviews may consult earlier works. $^{33}$

Regarding the availability of formal coursework on instruction, librarians and library educators including Sharon A. Hogan and Robert E. Brundin (among others) provide overviews of studies conducted since the 1970s that demonstrate the lack of well-articulated programs for providing professional education for instruction librarians through LIS programs. ${ }^{34}$ While studies conducted in the 1970s and 1980s demonstrated an almost complete absence of formal coursework on instruc- 
tion in LIS programs, more recent studies demonstrate an increasing availability of courses for preservice librarians with an interest in teaching. By the late 1990s, a majority of the LIS programs accredited by the American Library Association listed a separate course on instruction as an available elective, and others included an introduction to instructional issues as part of a more broadly focused course. ${ }^{35}$ Thus, while still not as widely available as some advocates might wish, formal coursework on instruction is increasingly part of the curriculum offered to preservice librarians (albeit often only as an irregularly scheduled elective course, or as a course required only of certain students-for example, those preparing for a career in school libraries).

Given the inconsistent availability of formal coursework on instruction in LIS programs over the past 30 years, other studies have explored the options that interested practitioners have pursued through continuing professional education. Hogan, for example, noted the range of continuing education opportunities available to instruction librarians provided through professional associations such as the American Library Association (ALA) and the Association of College \& Research Libraries (ACRL). Also significant was the emerging network of locally developed opportunities such as workshops and conference programs organized by academic libraries and regional library groups. Alice S. Clark and Kay F. Jones identified numerous approaches to continuing education and "on-the-job training" pursued by instruction librarians who had not been exposed to issues related to teaching and learning as part of their professional education. Mandernack reported that independent study and participation in workshops and professional conferences were the most common approaches used by Wisconsin librarians with a responsibility for instruction to learn more about this field. Patterson and Howell reported similar results after a national survey that found that consultation with faculty colleagues, attendance at workshops and professional conferences and independent study were the favored means of continuing education. Finally, Shonrock and Mulder found that on-the-job training, independent study, and formal education outside the field of library and information science were the primary means by which instruction librarians across the country gained mastery over a wide variety of professional competencies related to teaching and learning and to managing instructional service programs in libraries. ${ }^{36}$ Continuing education remains a critical resource for librarians learning to teach, and experience with seminars, workshops, and conference programs has been brought to the local level through increasingly sophisticated models for in-house orientation and professional development programs for teaching librarians. ${ }^{37}$

An array of preservice and continuing professional education opportunities are available for librarians interested in becoming better teachers, but what are the topics on which such opportunities focus? This is the least well defined area in the library literature, but initial conclusions may be drawn from a review of existing studies of instructional materials and core competencies.

As part of an ongoing research project sponsored through the ACRL Instruction Section, Shonrock and Mulder identified 84 discrete competencies relevant to the work of instruction librarians in areas including instructional design, pedagogy, assessment of student learning, oral and written communication, and program management. Among the most important competencies identified in this study were the abilities to:

- organize and structure ideas logically;

- deliver lectures, vary pace and tone, use eye contact, use appropriate gestures, etc.;

- provide clear, logical instructions;

- determine a reasonable amount and level of information to be presented in a lesson plan; 
- verbalize a search strategy; and

- understand student assignments and the role of the library in completing those assignments.

The authors provide a detailed list of how highly each of these (and other) competencies was rated by survey respondents, as well as notes on how each competency might be achieved in the contemporary environment for professional and continuing education. A review of the 25 most highly rated competencies shows that most relate to principles of instructional design, pedagogical skills, and basic instruction in information retrieval. Some, however, identify skills needed for the management of instructional services programs in libraries (for example, the ability to find the best paths of communication within the institution and use them to promote bibliographic instruction). Finally, a small number point to the need for an awareness of the broader organizational culture of higher education (for instance, demonstrating an understanding of faculty priorities and value systems to promote a bibliographic instruction program). ${ }^{38}$

The educational categories suggested by Shonrock and Mulder are reinforced by Larson and Meltzer, who reviewed syllabi from instruction-related courses in LIS programs and reported that the most common topics of study included the history of instructional services in libraries, fundamentals of teaching method, design of instructional materials, and techniques for assessment of student learning. While their data are now 20 years old, a brief review by the author of the course materials currently available online retrieved similar results. Mandernack reported that respondents to his survey of continuing education needs were most interested in topics related to program management, teaching methods, instructional design, and learning theory. Finally, Maureen Kilcullen identified learning theory, instructional design, pedagogical skills, and an understanding of faculty culture as the broad categories of knowledge of greatest importance to instruction librarians in academic libraries. ${ }^{39}$ Each of these studies suggests a focus on practical skills that can be applied in the classroom, and each of the areas identified as important for instruction librarians to master is well represented both in the in-house training programs that have remained popular in academic libraries (for example, at the University of Michigan, the University of Texas, and Washington State University) and in the "teacher track" of the ACRL "Immersion" program, which remains the leading continuing education program for instruction librarians. ${ }^{40}$

In sum, the education of instruction librarians has been defined largely in terms of practical teaching skills: that is, in many ways like the traditional model of teacher education criticized as less than complete by scholars such as Deborah Britzman and Robert V. Bullough, Jr. ${ }^{41}$ While librarians were continuing to design research studies aimed at answering very basic questions about the composition and availability of teacher training for librarians, teacher educators were breaking new ground by exploring the importance of teacher identity for those who will be expected to make regular use of those instructional design, pedagogical, and assessment skills introduced as part of teacher training. The final facet of the literature of significance to this study sheds light on professional identity development among librarians and public perceptions of the profession.

\section{Professional Identity and the Librarian}

Few professions are as sensitive to issues of professional identity and public perception as that of librarianship. ${ }^{42}$ This concern may be warranted, as Pauline Wilson identified a negative stereotype of the librarian found throughout twentieth-century American culture: that is, someone who is (among other things) introspective, socially conservative, concerned with adherence to rules and regulations, orderly, and submissive to authority. ${ }^{43}$ During the climax of the film, 
It's a Wonderful Life (1946), the horror expressed by George Bailey when he is told by his guardian angel that his wife has been doomed to life as a spinster librarian by his wish that he had never been born is palpable. As Robert D. Leigh and Kathryn W. Sewny wrote almost half a century ago, librarians want to be recognized as part of an intellectual profession but feel that public perception relegates them more often to the role of clerks. ${ }^{44}$ Mary Bailey appeared to be a public librarian; the situation for academic librarians is even more complicated.

Susan K. Martin referred to librarianship as an "accidental profession": that is, a field that one pursued "while detouring from some other planned career." ${ }^{45}$ Orvin Lee Shiflett and Stephen E. Atkins have noted that this perception is particularly problematic for academic librarians, who are surrounded by colleagues following the dominant campus profession of member of the teaching faculty. ${ }^{46}$ Atkins concluded that academic librarians lack a distinct professional identity in this environment, and Wilson argued that any attempt by academic librarians to define themselves as teachers was doomed to failure owing to the gulf between the professional responsibilities of academic librarians and those of members of the teaching faculty. ${ }^{47}$ Sheila D. Creth and Andrew D. Abbott have identified changes in the technological environment as helping to drive change in the professional role of librarians, and, more broadly, Rebecca Watson-Boone demonstrated how an environment of rapid change within academic libraries, as a whole, contributes to the evolution of new (and sometimes contradictory) professional identities. ${ }^{48}$ Finally, Herbert S. White argued that academic librarians will need to make an informed choice about which professional identity to embrace if they are to remain relevant within the equally volatile environment of higher education writ large. ${ }^{49}$

Research on professional identity among librarians (that is, the way that librarians perceive their own work) is actually rather limited. A far richer literature revolves around studies like Wilson's of stereotypes and the ways in which others perceive the librarian's work. Gary M. Church provides an historical overview of popular stereotypes about librarians, as well as of related studies of the place of academic librarians in campus culture. More specific studies include those by Earl Tannebaum, who examined the depiction of librarians in novels set in colleges and universities; Ann O'Brien and Martin Raish, who examined the depiction of librarians on film; and Doug Highsmith and Elaine Yontz, who examined the depiction of librarians, respectively, in comic books and children's literature. ${ }^{50}$ Church also includes the question of faculty rank and status for academic librarians as part of his discussion, but space will not allow a consideration of that extensive literature here. Interested readers will find useful syntheses of the literature on professionalism and faculty status for academic librarians in recent works by Michael Gordon Jackson and Danielle Bodrero Hoggan. ${ }^{51}$

In addition to studies of professional identity and of popular stereotypes of the profession, there have been a small number of studies exploring the perceptions of college students and faculty of their librarian colleagues. Danuta A. Nitecki, for example, examined letters and opinion pieces published in the Chronicle of Higher Education to identify the predominant metaphors used by faculty members, librarians, and administrators to describe libraries. ${ }^{52}$ Peter Hernon and Maureen Pastine explored student perceptions of the librarian's role on campus and found that, in general, students have a very limited understanding of the full range of professional responsibilities held by academic librarians and, further, that they do not perceive librarians to be an integral part of the instructional process. Few students understood the educational background of academic librarians, and many perceived the roles of librarians, 
support staff, and even student assistants as equivalent. ${ }^{53}$ Jody Fagan reported largely similar findings when she updated the Hernon and Pastine survey more than 25 years after the original study. ${ }^{54}$ Larry R. Oberg, Mary Kay Schleiter, and Michael Van Houten found that many faculty share their students' inability to consistently distinguish between librarians and support staff as well as a similarly truncated vision of the scope of librarian work. Pertinent to the present study, they also found that relatively few faculty members were aware of the range of instructional responsibilities held by many academic librarians, and that many did not consider teaching to be a significant responsibility for librarians when compared with other responsibilities that they associated with the profession..$^{55}$ Similar results were reported in studies of faculty perceptions of librarians by Gaby Divay, Ada M. Ducas, and Nicole Michaud-Oystryk, and by Robert T. Ivey. ${ }^{56}$ As each of these studies concludes, a lack of understanding across campus of the academic librarian's professional role and responsibilities can have significant implications for issues such as compensation, roles in campus governance, access to resources and support services, and, most importantly, the level of budgetary support allocated to libraries by campus administration. Certainly, they can have a direct effect on the degree to which a librarian is able to pursue his or her work as a teacher.

Teaching is an increasingly significant responsibility for academic librarians, but it is a responsibility that has historically been less than fully appreciated by college students, faculty, and administrators. Moreover, it is a role for which few librarians are prepared during their preservice professional education. Finally, even the introduction to teaching that is made available to librarians through continuing education and other programs focuses primarily on basic instructional skills. Teacher training of this sort provides a critical foundation for librarians who find themselves unceremoniously thrust into the classroom, and the need for it will not diminish. Simple mastery of basic instructional competencies, however, will not help librarians to develop the sort of teacher identity that research in teacher education suggests is important to their ongoing professional development. By casting the discussion about the education of instruction librarians as part of the broader discussion of learning to teach and teacher identity, we may learn more about how academic librarians can present a well-defined professional identity to campus colleagues who have historically misunderstood their work.

\section{Themes in the Study of Teacher Identity Among Academic Librarians}

Studies of teacher identity rely strongly on personal narrative to help us to understand the biographical events that help to shape teacher identity and a commitment to joining the teaching profession. Reflection on teacher identity as part of preservice teacher education may also help students to develop the habits of personal reflection that contribute to their development as critical and reflective practitioners. Following this model, the present study made use of semistructured interviewing to elicit personal narratives from a group of academic librarians regarding their experience as teachers and as librarians committed to promoting their instructional role on campus.

Interviews lasting between 45 and 90 minutes each were conducted during spring 2004 with six librarians (5 female, 1 male) whose length in professional service ranged from 2 to 32 years (see Appendix One for interview schedule). One of the participants had professional experience as a teacher prior to becoming a librarian, while another had professional experience as a public librarian prior to taking her current position. All of the participants were employed together at a research library serving an institution classified by the Carnegie Founda- 
tion for the Advancement of Teaching as "Doctoral/Research-Extensive." Data collected through the interviews were reviewed throughout the process using field memos and a research log and were then analyzed using a coding process by which discrete ideas emergent from the data were used to identify a small number of themes around which the study of teacher identity among academic librarians might begin. Finally, the initial conclusions enumerated below were validated through member checking during the writing phase..$^{57}$

\section{The Centrality of Teaching}

Teaching is a core focus for the work of these academic librarians, both in terms of the amount of time they spend providing instruction in the classroom and the way they approach other aspects of their work. As one participant noted, "the teaching function comes out in everything that you do." Another saw her instructional role as coloring her approach to work at the reference desk and as a collection manager. "Even when I'm not in the classroom," she concluded, "I'm always teaching." While one participant allowed that "there are plenty of people who are in public services librarianship who never really intended to do much teaching and probably don't see it as a high priority," each of the participants in this study identified strongly with the role of librarian as teacher and sought out positions where that role was valued. For these librarians, questions of whether or not the word "instruction" appeared in their job title or whether or not their position descriptions included a formal responsibility for instruction are immaterial. They took their positions because of the opportunity each provided to contribute to the library and to the university as a teacher. Studies like Elmborg's that explore the ways in which traditional professional responsibilities are recast by a focus on teaching as the core responsibility for the academic librarian resonate with the ideas expressed by the participants in this study. ${ }^{58}$

\section{The Importance of Collegial and Adminis- trative Support}

Support from colleagues, professional role models, and supervisors is critical to the librarian's ability to focus on his or her work as a teacher. As one participant noted:

When I'm in the classroom, I'm not here [in the library], and we have some significant staffing issues here. So, if I'm teaching, support from my supervisor is important because when a faculty member says "I'd like you to teach," I know that my supervisor will say "Great!," instead of "You can't."

The importance of colleagues willing to help provide backup service on reference desks and in other venues to give teaching librarians the freedom to be in the classroom or to contribute to campuswide instructional initiatives was acknowledged almost universally by participants in this study. Also noted was the importance of support among the library administration for the teaching role, as evidenced by the allocation of human resources to a library instruction unit and the provision of support for instructional initiatives. In an earlier study, the author reviewed the literature of higher education in regard to the importance of administrative support for college faculty seeking to focus on their work as teachers, and the conclusions of that study regarding the importance of administrative support for instructional initiatives in academic libraries are echoed in this study at the level of the individual librarian. ${ }^{59}$

\section{The Stress of Multiple Demands}

While each of the participants in this study expressed a strong commitment to his or her role as a teacher, it was clear that more than one felt personal stress as the result of multiple demands on their time. This theme was echoed across many of the interviews with participants noting that time dedicated to teaching was often 
taken from other responsibilities. "You never have enough time," one participant noted, "I don't think I know my collection enough; I don't think I know my resources enough." Another participant who had experience teaching at the $\mathrm{K}-12$ level identified this as a challenge distinctive of the higher education environment:

One of the things that I've found is quite a bit different than teaching at the $\mathrm{K}-12$ level is that there's just more... there seems to be more things, committee work, more things going on that pull you in a lot of different directions as an academic librarian. A lot of different things. You have to strive to, you know, achieve excellence in a number of different areas, and I'm still struggling with the idea of how all of those things fit together as a whole and how to establish priorities amongst those different kinds of pulls. There are times when I'm very frustrated and I feel that I'm giving sort of a half-baked effort to a whole slew of things, rather than really focusing on being... on trying to excel in one particular area.

Patterson and Howell identified the pull of multiple demands on one's time as a leading cause of stress and burnout among instruction librarians, and Peter Seldin has drawn the same conclusion about teaching faculty more broadly. ${ }^{60}$ While none of the participants in the current study showed signs of burnout, it is clear that this remains an important issue for teaching librarians.

\section{The Problems with Professional Education}

"My library school education did not really prepare me for the importance of instruction in the profession." While the interview schedule did not include any questions specific to professional education, several participants introduced the topic independently. Rather than focus on the question of whether or not an in- struction-related course was available to them when they completed their preservice education, however, they identified previously unexplored issues related to their educational program. Westbrook, for example, concludes that the place of instruction in the LIS curriculum is improving based simply on the number of courses now available, but how are those courses conducted and how are they perceived by students? ${ }^{61}$ One participant who completed a course on instruction during library school was critical of its content: "I took the library instruction class, but, based on this library instruction class, I didn't walk away with an idea that this was such a big thing because the class was not a very well-done class, it was just sort-of slap-dash thrown together." Another participant concurred about the perception left regarding the importance of instruction for the day-to-day work of an academic librarian while discussing the course that he chose not to take:

Where I went to library school, there was one class on instruction. Of all the different classes, you know, whatever number of offerings, hundreds of offerings, [there was only one] that focused on instruction. Now, there were oodles of classes on different kinds of reference focuses, and I took a lot of those classes-business reference, medical reference-which obviously helps with teaching, too, but there's only one that was specifically for [instruction]. So, from that standpoint, I would have concluded: "Oh well, this must not be a significant priority in the profession right now because there's only one class specifically on this issue."

A number of studies have explored the simple question of the availability of instruction-related courses in LIS programs, but the responses of these participants suggest that there are a number of more complex questions requiring study. For 


\section{A Qualitative Inquiry into Professional Identity 63}

example, what is taught in the instruction courses that are available and does it provide future librarians with an introduction not only to pedagogical skills, but also to the broader instructional context into which they will be coming as public, school, special, or academic librarians? What is the place of the instruction course in the curriculum (for example, is it a core course, or required only of future school librarians)? Is the instruction course, when offered, taught by a permanent member of the faculty (tenured or tenure track), or is it a course populated by adjuncts who have a limited voice on decisions about the curriculum and departmental priorities? There is a rich literature on the education of instruction librarians, but even this initial qualitative inquiry indicates that there are many important questions yet to be answered.

\section{Stereotypes and Misperceptions}

A final theme emergent from the data has to do with stereotypes. Studies of college students and college faculty suggest that the academic library profession is poorly understood by those outside it. This perception was shared by participants in this study, who believed that many of their campus colleagues were either unaware of what they did, or under mistaken impressions fueled by stereotypes in the popular culture. Two comments are especially interesting for the different facets of this complicated problem that they illuminate.

Overall, I think people are pretty much unaware of what we do. Probably what they perceive that we do is collect, we build the collections, we're collectors is primarily what I think they see us doing.

\section{$* * *$}

The people who have negative attitudes about librarians or think that all we do is, you know, that we're secretaries, or that we put stickers on things, or whatever they think we do ... [what] they don't understand is that organizing all of human knowledge in an easy-to-use way is a really daunting task.

Earlier studies of campus perceptions of academic librarians have identified collections work both as a valuable professional activity that is largely invisible to faculty and students, and as an activity around which faculty and librarians may come into conflict. ${ }^{62}$ In the first excerpt, the image of the librarian as keeper of collections is posed as an outmoded image that fails to accommodate the image of librarian as teacher to which this participant was committed. While the second excerpt demonstrates concern about the long-held stereotype of the librarian as clerk, it also echoes conclusions drawn by Abbott, White, and others regarding the need to recast ancient professional responsibilities in a new way. ${ }^{63}$ The Google company mission statement is "[to] organize the world's information and make it universally accessible and useful"; the comments by the second participant suggest that this mission may be better appreciated by campus colleagues when espoused by a search engine giant rather than by local librarians. ${ }^{64}$

\section{Discussion and Implications for Future Research}

As noted throughout this essay, the aim of this study was largely exploratory. The themes identified above as significant to the study of teacher identity among academic librarians were derived from a purposively selected sample of academic librarians who the author knew were strongly committed to their role as teachers. ${ }^{65}$ Moreover, the limited time available for interviewing did not allow for complete "saturation" of the data: that is to say, there were ideas expressed by one or two participants that did not rise to the level of "theme" based on the current pool of participants, but that have promise as topics that might be explored with future participants (see, for 
example, the brief discussion of the issue of mentoring provided below) ${ }^{66}$ Finally, a participant pool that represented the full range of opinion among academic librarians regarding the importance of teaching as a professional responsibility would undoubtedly bring to the surface a much more complex set of themes among professionals who, as Watson-Boone and White both noted, have multiple professional identities from which to choose. ${ }^{67}$ Thus, while one cannot conclude that this study provides a well-articulated and grounded theory of teacher identity adoption and development among academic librarians, even an exploratory study may provide important insight into some of the research questions suggested by the literature of "learning to teach" and of teacher identity.

For example, while previous studies have explored the lack of formal introduction to teaching in professional education programs for librarians, this study suggests that continuing lack of attention to this issue results in a difficult introduction into the profession for new academic librarians. Most of the participants in this study shared the feeling that they were not prepared for the amount of time they would be required to dedicate to instruction in their first professional position by the way in which teaching and learning, as a field of study, was treated in their professional education programs. Their success in those positions, they said, was based in large part on the support of colleagues and, especially, on one or two role models or mentors each found who shared their interest in teaching. Patterson and Howell noted the importance of collegial support for instruction librarians, and Walter concluded that a collegial network was critical to instructional improvement among academic librarians. ${ }^{68}$ Scott Walter and Lisa Janicke Hinchliffe, however, found that orientation and mentoring programs focused on the librarian's role as teacher are not yet a common resource in academic libraries. ${ }^{69}$ Given that participants in this study suggest that both can be critical to the successful introduction of the academic librarian to his or her role as teacher, future research on orientation and mentoring programs for teaching librarians should inform the development and wider adoption of such programs among academic libraries.

Also in regard to professional and continuing education, this study suggests that there are a number of important questions about the content and conduct of these opportunities for instruction librarians that have not been explored in the literature. An analysis of the content areas actually included as part of formal coursework on instruction in professional education programs, for example, would extend the literature in this area, as would a study of the impact on professional development among teaching librarians of more focused attention to the idea of teacher identity as an important facet of their broader professional identity as librarians. Studies of preservice teacher education provide a framework for engaging in such research as part of an instruction course offered in an LIS program, while studies of mid-career teachers suggest ways in which this issue might be explored with experienced practitioners as part of continuing education opportunities.

Finally, this study suggests that there is an important connection between research on student perceptions of academic librarians, the study of teacher identity, and the future of the profession. Recall the focus in the teacher education literature on what Lortie called the "apprenticeship of observation." ${ }^{70}$ Like the work of teachers, the work of librarians is observed directly by the students we employ. Studies by Hernon and Pastine and by Fagan, however, suggest that this work is greatly misunderstood and that, in particular, few students understand or appreciate the librarian's role as teacher in the higher education environment. ${ }^{71}$ Recruitment has been identified as one of the most important challenges currently facing the academic library profession. ${ }^{72}$ If scholars are correct that decisions about 


\section{A Qualitative Inquiry into Professional Identity 65}

joining a teaching profession may be influenced in important ways by how one is introduced to the profession during this "apprenticeship," it is critical that students be provided with a better opportunity to understand the full range of our professional responsibilities. If Martin is correct that academic librarianship is often a profession that one embraces on the way to (or from) another field, it is all the more important that those who might have an interest in college teaching are given an opportunity to appreciate how significant a feature of our work that teaching has become in the contemporary higher education environment. ${ }^{73}$

\section{Conclusion}

Thirty-five years ago, Kenneth Eble embarked on a national study of college teaching in which he identified, among other things, a conflict between the faculty member's role as teacher and his or her role as researcher. ${ }^{74}$ Innumerable studies have been conducted since then that reflect the basic issue of the faculty member's need to balance multiple professional responsibilities as part of his or her identity as a college professor, including, most commonly, responsibilities for teaching, research, and service. How much more complex is this problem for academic librarians, many of whom are likewise responsible for research and service, but for whom even teaching competes with equally important professional responsibilities for the provision of information services, the development and preservation of print and electronic collections, and the creation of information systems that provide access to those resources, services, and collections? White argued that the academic librarian is now faced with a choice of two professional identities (the "bookman" or the "knowledge worker"), but the situation is hardly so simple. ${ }^{75}$

Numerous studies of contemporary practice in academic libraries demonstrate that the role of the librarian as teacher is increasingly important. Contrary to what some critics have suggested, this is not the result of academic librarians seeking to enhance their professional status on campus by associating their work with the most visible feature of the work of the college professor, but is simply evidence of a far-reaching change in the profession of college teaching itself. ${ }^{76}$ As Gary Rhoades has noted, one of the most significant issues facing faculty in the 21 st century is the expanding responsibility for direct instruction on campus by student affairs educators, librarians, and other academic professionals drawn from outside the ranks of the traditional teaching faculty. ${ }^{77}$ The rise of interdisciplinary instructional initiatives such as General Education, First-Year Experience, and Writing Across the Curriculum, too, have not only provided increasing instructional opportunities for academic librarians, but have all but required academic libraries to focus on teaching as a core service. Lack of a consistent teacher identity among academic librarians may hinder their effectiveness in meeting these expanding instructional responsibilities in a changing organizational environment.

Watson-Boone noted that librarian voices are often absent from the literature of academic librarianship..$^{78}$ It might be more accurate to say that their voices are typically aggregated and presented in an impersonal way through reports of local, regional, and national surveys. Application of qualitative research methods such as interviewing provides an opportunity to restore the voice of individual librarians to the literature while still coming to conclusions that can inform broader scholarly inquiry and professional practice. Qualitative inquiry has proven useful in a number of fields already, including the study of user perceptions of the library and assessment of library services, and the framework provided in this study from research in the field of teacher education suggests that there are rich opportunities still available for similarly framed inquiry into the experience of the librarian as teacher. 


\section{Notes}

1. John M. Budd, The Changing Academic Library: Operations, Cultures, Environments (Chicago: Association of College \& Research Libraries, 2005); Sheila D. Creth, "A Changing Profession: Central Roles for Academic Librarians," Advances in Librarianship 19 (1995): 85-98; Beverly P. Lynch and Kimberley R. Smith, "The Changing Nature of Work in Academic Libraries," College $\mathcal{E}$ Research Libraries 62, no. 5 (2001): 407-20; Rebecca Watson-Boone, Constancy and Change in the Worklife of Research University Librarians (Chicago: Association of College \& Research Libraries, 1998).

2. Lori Arp and Beth S. Woodard, "Recent Trends in Information Literacy and Instruction," Reference E User Services Quarterly 42, no. 2 (2002): 124-32; Abby Kassowitz-Scheer and Michael Pasqualoni, "Information Literacy Instruction in Higher Education: Trends and Issues" [ERIC Digest ED 465 375] (2002), available online at www.ericdigests.org/2003-1/information.htm [accessed 25 July 2006]; Ilene F. Rockman, ed., Integrating Information Literacy in the Higher Education Curriculum: Practical Models for Transformation (San Francisco: Jossey-Bass, 2004).

3. On the history of information literacy instruction, see Frances L. Hopkins, "A Century of Bibliographic Instruction: The Historical Claim to Professional and Academic Legitimacy," College E Research Libraries 43, no. 3 (1982): 192-98; Mary F. Salony, "The History of Bibliographic Instruction: Changing Trends from Books to the Electronic World," The Reference Librarian, no. 51/52 (1995): 31-51; and John M. Tucker, "User Education in Academic Libraries: A Century in Retrospect," Library Trends 29, no. 1 (1980): 9-27. On the evolving role of the librarian as teacher, see Betsy Baker and Mary Ellen Litzinger, eds., The Evolving Educational Mission of the Library (Chicago: Association of College \& Research Libraries, 1992); Evan I. Farber, "College Libraries and the Teaching/Learning Process: A 25-Year Reflection," Journal of Academic Librarianship 25, no. 3 (1999): 171-77; Hannelore B. Rader, "Information Literacy and the Undergraduate Curriculum," Library Trends 44, no. 2 (1995): 270-78; and Hannelore B. Rader, "Educating Students for the Information Age: The Role of the Librarian," Reference Services Review 25, no. 2 (1997): 47-52.

4. University of Virginia Libraries, ARL Statistics: Interactive Edition (2005), available online at http://fisher.lib.virginia.edu/arl/index.html [accessed 25 July 2006].

5. Lynch and Smith, "The Changing Nature of Work in Academic Libraries"; Rebecca Albrecht and Sara Baron, "The Politics of Pedagogy: Expectations and Reality for Information Literacy in Librarianship," Journal of Library Administration 36, no. 1/2 (2002): 71-96; Charles D. Patterson and Donna W. Howell, "Library User Education: Assessing the Attitudes of Those Who Teach," RQ 29, no. 4 (1990): 513-24.

6. Chris Avery and Kevin Ketchner, "Do Instruction Skills Impress Employers?" College $\mathcal{E}$ Research Libraries 57, no. 3 (1996): 249-53, 256-58; Christopher Bober et al., "Evaluating Library Instruction in Academic Libraries: A Critical Review of the Literature, 1980-1993," The Reference Librarian, no. 51/52 (1995): 53-71; Francine DeFranco and Richard Bleiler, Evaluating Library Instruction [ARL SPEC Kit No. 279] (Washington, D.C.: Association of Research Libraries, 2003); Lorrie A. Knight, "The Role of Assessment in Library User Education," Reference Services Review 30, no. 1 (2002): 15-24; Scott Walter, "Improving Instruction: What Librarians Can Learn from the Study of College Teaching," in Currents and Convergence: Navigating the Rivers of Change: Proceedings of the Twelfth National Conference of the Association of College E Research Libraries, April 7-10, 2005, Minneapolis, Minnesota, ed. Hugh A. Thompson, 363-79 (Chicago: Association of College \& Research Libraries, 2005).

7. James K. Elmborg, “Teaching at the Desk: Toward a Reference Pedagogy," portal: Libraries and the Academy 2, no. 3 (2002): 455-64; Richard Fyffe and Scott Walter, "Building a New Future: 'Preparing Future Faculty' and 'Responsible Conduct of Research' Programs as a Venue for Scholarly Communication Discussions," College E Research Libraries News 66, no. 9 (2005): 654-56, 663.

8. Scott B. Mandernack, "An Assessment of Education and Training Needs for Bibliographic Instruction Librarians," Journal of Education for Library and Information Science 30, no. 3 (1990): 193-205.

9. Patterson and Howell, "Library User Education."

10. Albrecht and Baron, "The Politics of Pedagogy"; Mary Ellen Larson and Ellen Meltzer, "Education for Bibliographic Instruction," Journal of Education for Library and Information Science 28, no. 1 (1987): 9-25; Brigit Shea Sullivan, "Education for Library Instruction: A 1996 Survey," Research Strategies 15, no. 4 (1997): 271-77.

11. Diana Shonrock and Craig Mulder, "Instruction Librarians: Acquiring the Proficiencies Critical to Their Work," College E Research Libraries 54, no. 2 (1993): 137-49.

12. Albrecht and Baron, "The Politics of Pedagogy"; Elizabeth Blakesley Lindsay and Sara 


\section{A Qualitative Inquiry into Professional Identity 67}

Baron, "Leading Information Literacy Programs: Immersion and Beyond," Journal of Library Administration 36, no. 1/2 (2002): 143-65.

13. Deborah P. Britzman, Practice Makes Practice: A Critical Study of Learning to Teach (Albany: State University of New York Press, 1991); Kathy Carter and Walter Doyle, "Personal Narrative and Life History in Learning to Teach," in Handbook of Research on Teacher Education, 2nd ed., John P. Sikula, Thomas J. Buttery, and Edith Guyton, eds., 120-42 (New York: Macmillan, 1996); Ivor F. Goodson, ed., Studying Teachers' Lives (New York: Teachers College Press, 1992); Vicky J. Swedenburg, Developing and Sustaining a Professional Identity: A Qualitative Study of Social Studies Teachers at Mid-Career. Ph.D. diss., University of Minnesota, 2001; Kathleen A. Travers, Exploring the Development of Teacher Identity: A Study of Prospective Teachers Learning to Teach. Ph.D. diss., University of Wisconsin-Madison, 2000; Watson-Boone, Constancy and Change in the Worklife of Research University Librarians.

14. For general discussions of qualitative research methods, see Sharan B. Merriam, Qualitative Research and Case Study Applications in Education, 2nd ed.. (San Francisco: Jossy-Bass, 1998); Irving Seidman, Interviewing as Qualitative Research: A Guide for Researchers in Education and the Social Sciences, 2nd ed. (New York: Teachers College Press, 1998); Robert S. Weiss, Learning from Strangers: The Art and Method of Qualitative Interview Studies (New York: Free Press, 1994); Richard A. Krueger and Mary Anne Casey, Focus Groups: A Practical Guide for Applied Research, 3rd ed. (Thousand Oaks, Calif.: Sage, 2000); and Henry F. Wolcott, The Art of Fieldwork (Walnut Creek, Calif.: AltaMira Press, 1995). For discussions of the use of qualitative research methods in library and information science research, see Jana Bradley and Brad Sutton, "Reframing the Paradigm Debate," Library Quarterly 63, no. 4 (1993): 405-10; Jack D. Glazier and Ronald R. Powell, eds., Qualitative Research in Information Management (Englewood, Colo.: Libraries Unlimited, 1992); Constance A. Mellon, Naturalistic Inquiry for Library Science: Methods and Applications for Research, Evaluation, and Teaching (New York: Greenwood Press, 1990); and Lynn Westbrook, "Qualitative Research" in Basic Research Methods for Librarians, 3rd ed., Ronald R. Powell, ed., 143-63 (Westport, Conn.: Ablex, 1997).

15. Martin J. Brennan et al., "A Snapshot of Early Adopters of E-Journals: Challenges to the Library," College \& Research Libraries 63, no. 6 (2002): 515-26; David Ellis, "Modeling the Information-Seeking Patterns of Academic Researchers: A Grounded Theory Approach," Library Quarterly 63, no. 4 (1993): 469-86; Wendy M. Duff and Cathy A. Johnson, "Accidentally Found on Purpose: Information-Seeking Behavior of Historians in Archives," Library Quarterly 72, no. 4 (2002): 472-96; Colleen Cook and Fred M. Heath, "Users' Perceptions of Library Service Quality: A LIBQUAL+ Qualitative Study," Library Trends 49, no. 4 (2001): 548-84; Jennifer Mendelsohn, "Perspectives on Quality of Reference Services in an Academic Library: A Qualitative Study," RQ 36, no. 4 (1997): 544-57.

16. Mark Sandler, "Qualitative Research Methods in Library Decision-Making," in Qualitative Research in Information Management, Jack D. Glazier and Ronald R. Powell, eds. (Englewood, Colo.: Libraries Unlimited, 1992), 174-86; Cook and Heath, “Users' Perceptions of Library Service Quality"; Nicole Campbell, ed., Usability Assessment of Library-Related Web Sites: Methods and Case Studies (Chicago: Library \& Information Technology Association 2001).

17. Christine Bruce, The Seven Faces of Information Literacy (Adelaide, Australia: AUSLIB Press, 1997); Kate Manuel, Susan Beck, and Molly Molloy, "An Ethnographic Study of Attitudes Influencing Faculty Collaboration in Library Instruction," The Reference Librarian, no. 89/90 (2005): 139-61; Nan H. Seamans, "Student Perceptions of Information Literacy: Insights for Librarians," Reference Services Review 30, no. 2 (2002): 112-23.

18. Donald Ary, Lucy Cheser Jacobs, and Asghar Razavieh, Introduction to Research in Education, 6th ed. (Belmont, Calif.: Wadsworth, 2002), 425 .

19. Ary, Jacobs, and Razavieh, Introduction to Research in Education; Anselm Strauss and Juliet Corbin, Basics of Qualitative Research: Techniques and Procedures for Developing Grounded Theory, 2nd ed. (Thousand Oaks, Calif.: Sage, 1998).

20. John W. Cresswell, Research Design: Qualitative, Quantitative, and Mixed Methods Approaches, 2nd ed. (Thousand Oaks, Calif.: Sage, 2003), 30.

21. Carter and Doyle, "Personal Narrative and Life History in Learning to Teach"; Travers, Exploring the Development of Teacher Identity.

22. Britzman, Practice Makes Practice, 120.

23. Britzman, Practice Makes Practice; Robert V. Bullough, Jr. and Andrew D. Gitlin, Becoming a Student of Teaching: Linking Knowledge Production and Practice, 2nd ed. (New York: RoutledgeFarmer, 2001).

24. Douwe Beijaard, Nico Verloop, and Jan D. Vermunt, "Teachers' Perceptions of Professional Identity: An Exploratory Study from a Personal Knowledge Perspective," Teaching and Teacher Education 16 (2000): 749-64; Britzman, Practice Makes Practice; Bullough and Gitlin, Becoming a Student of Teaching; Robert V. Bullough, Jr., J. Gary Knowles, and Nedra A. Crow, Emerging as a 
Teacher (New York: Routledge, 1991); Carter and Doyle, "Personal Narrative and Life History in Learning to Teach"; J. Gary Knowles, "Models for Understanding Preservice and Beginning Teachers' Biographies: Illustrations from Case Studies," in Studying Teachers' Lives, Ivor F. Goodson, ed., 99-152 (New York: Teachers College Press, 1992); Travers, Exploring the Development of Teacher Identity.

25. For studies of professional identity issues among experienced practitioners, see Antoinette Mitchell, "Teacher Identity: A Key to Increased Collaboration," Action in Teacher Education 19, no. 3 (1997): 1-14; and Swedenburg, Developing and Sustaining a Professional Identity. 99.

26. Knowles, "Models for Understanding Preservice and Beginning Teachers' Biographies,"

27. Beijaard, Verloop, and Vermunt, "Teachers' Perceptions of Professional Identity"; Swedenburg, Developing and Sustaining a Professional Identity.

28. Swedenburg, Developing and Sustaining a Professional Identity.

29. Dan C. Lortie, Schoolteacher: A Sociological Study (Chicago: University of Chicago Press, 1975), 61.

30. Knowles, "Models for Understanding Preservice and Beginning Teachers' Biographies."

31. Beijaard, Verloop, and Vermunt, "Teachers' Perceptions of Professional Identity"; Swedenburg, Developing and Sustaining a Professional Identity; Travers, Exploring the Development of Teacher Identity.

32. Robert E. Brundin, "Education for Instructional Librarians: Development and Overview," Journal of Education for Library and Information Science 25, no. 3 (1985): 177-89; Sharon A. Hogan, "Training and Education of Library Instruction Librarians," Library Trends 29, no. 1 (1980): 105-26; Larson and Meltzer, "Education for Bibliographic Instruction"; Mandernack, "An Assessment of Education and Training Needs for Bibliographic Instruction Librarians"; Yvonne N. Meulemans and Jennifer Brown, "Educating Instruction Librarians: A Model for Library and Information Science Education," Research Strategies 18, no. 4 (2001): 253-64; Sullivan, "Education for Library Instruction"; Lynn Westbrook, "Passing the Halfway Mark: LIS Curricula Incorporating User Education Courses," Journal of Education for Library and Information Science 40, no. 2 (1999): 92-98.

33. Lindsay and Baron, "Leading Information Literacy Programs"; Meulemans and Brown, "Educating Instruction Librarians"; Walter, "Improving Instruction."

34. Hogan, "Training and Education of Library Instruction Librarians"; Brundin, "Education for Instructional Librarians"; Larson and Meltzer, "Education for Bibliographic Instruction"; Lindsay and Baron, "Leading Information Literacy Programs."

35. For representative studies, see Hogan, "Training and Education of Library Instruction Librarians"; Larson and Meltzer, "Education for Bibliographic Instruction"; Westbrook, "Passing the Halfway Mark"; and Albrecht and Baron, "The Politics of Pedagogy."

36. Hogan, "Training and Education of Library Instruction Librarians"; Alice S. Clark and Kay F. Jones, eds., Teaching Librarians to Teach: On-the-Job Training for Bibliographic Instruction Librarians (Metuchen, N.J.: Scarecrow Press, 1986); Mandernack, "An Assessment of Education and Training Needs for Bibliographic Instruction Librarians"; Patterson and Howell, "Library User Education"; Shonrock and Mulder, "Instruction Librarians: Acquiring the Proficiencies Critical to Their Work." For another perspective on continuing education programs in academic libraries during this period, see Janet Carson, "Training Librarians to Teach: A Continuing Education Prospect," in A Place to Stand: User Education in Canadian Libraries, Elizabeth Frick, ed., 227-56 (Ottawa, Ontario: Canadian Library Association, 1988).

37. For a current listing of continuing education opportunities for instruction librarians, see Instruction Section, Association of College \& Research Libraries, "Sponsors of Continuing Education Programs for Library Instruction (2005), available online at www.ala.org/ala/acrlbucket/ is/iscommittees/webpages/educationa/sponsors.htm [accessed 24 July 2006]. For discussions of in-house training programs for instruction librarians, see Walter, "Improving Instruction"; and Scott Walter and Lisa Janicke Hinchliffe, Instructional Improvement Programs [ARL SPEC Kit No. 287] (Washington, D.C.: Association of Research Libraries, 2005).

38. Shonrock and Mulder, "Instruction Librarians: Acquiring the Proficiencies Critical to Their Work," 142-44.

39. Larson and Meltzer, "Education for Bibliographic Instruction," 14; Instruction Section, Association of College \& Research Libraries, "Library Instruction Courses Offered by Accredited Master's Programs in Library and Information Studies" (2005), available online at www.ala.org/ ala/acrlbucket/is/iscommittees/webpages/educationa/libraryschools.htm [accessed 24 July 2006]; Mandernack, "An Assessment of Education and Training Needs for Bibliographic Instruction Librarians," 199; Maureen Kilcullen, "Teaching Librarians to Teach: Recommendations on What We Need to Know," Reference Services Review 26, no. 2 (1998): 7-18.

40. University Library, University of Michigan, "University Library Instructor College Curriculum" (2006), available online at www.lib.umich.edu/icollege/curriculum.html [accessed 24 July 


\section{A Qualitative Inquiry into Professional Identity 69}

2006]; University of Texas Libraries, “Tips and Techniques for Library Instruction” (2005), available online at www.lib.utexas.edu/services/instruction/tips/ [accessed 24 July 2006]; Washington State University Libraries, "Library Instruction Update" (2006), available online at www.wsulibs.wsu. edu/usered/update/index.htm [accessed 24 July 2006]; Institute for Information Literacy, Association of College \& Research Libraries, "Welcome to the ACRL Institute for Information Literacy" (2006), available online at www.ala.org/ala/acrl/acrlissues/acrlinfolit/professactivity/iil/welcome. htm [accessed 24 July 2006].

41. Britzman, Practice Makes Practice; Bullough and Gitlin, Becoming a Student of Teaching.

42. Andrew D. Abbott, "Professionalism and the Future of Librarianship," Library Trends 46, no. 3 (1998): 430-43; Wendi Arant and Candace R. Benefiel, "Introduction," The Reference Librarian, no. 78 (2002).

43. Pauline Wilson, Stereotype and Status: Librarians in the United States (Westport, Conn.: Greenwood Press, 1982), 9.

44. Robert D. Leigh and Kathryn W. Sewny, "The Popular Image of the Library and the Librarian," Library Journal 85, no. 11 (1960): 2089-91.

45. Susan K. Martin, "The Accidental Profession," Journal of Academic Librarianship 21, no. 3 (1995): 198.

46. Orvin Lee Shiflett, Origins of American Academic Librarianship (Norwood, NJ: Ablex, 1981): Stephen E. Atkins, The Academic Library in the American University (Chicago: American Library Association, 1991).

47. Atkins, The Academic Library in the American University; Pauline Wilson, "Librarians as Teachers: The Study of an Organizational Fiction," Library Quarterly 49, no. 2 (1979): 146-62.

48. Creth, "A Changing Profession"; Abbott, "Professionalism and the Future of Librarianship"; Watson-Boone, Constancy and Change in the Worklife of Research University Librarians.

49. Herbert S. White, "The Successful Future of the Librarian: Bookman or Knowledge Worker?," Australian Academic \& Research Libraries 34, no. 1 (2003), available online at http://alia. org.au/publishing/aarl/34.1/full.text/white.html [accessed 25 July 2006].

50. Gary M. Church, "In the Eye of the Beholder: How Librarians Have Been Viewed Over Time," The Reference Librarian, no. 78 (2002): 5-24; Earl Tannenbaum, "The Librarian in the College Novel," College \& Research Libraries 24, no. 3 (1963): 248-50; Ann O’Brien and Martin Raish, "The Image of the Librarian in Commercial Motion Pictures: An Annotated Filmography," Collection Management 17, no. 3 (1993): 61-84; Doug Highsmith, "The Long, Strange Trip of Barbara Gordon: Images of Librarians in Comic Books," The Reference Librarian, no. 78 (2002): 61-83; Elaine Yontz, "Librarians in Children's Literature: 1909-2000," The Reference Librarian, no. 78 (2002): 85-96.

51. Michael Gordon Jackson, "Image and Status: Academic Librarians and the New Professionalism," Advances in Librarianship 23 (2000): 93-115; Danielle Bodrero Hoggan, "Faculty Status for Librarians in Higher Education," portal: Libraries and the Academy 3, no. 3 (2003): 431-45.

52. Danuta A. Nitecki, "Conceptual Models of Libraries Held by Faculty, Administrators, and Librarians: An Exploration of Communications in the Chronicle of Higher Education," Journal of Documentation 49, no. 3 (1993): 255-77.

53. Peter Hernon and Maureen Pastine, "Student Perceptions of Academic Librarians," College E Research Libraries 38, no. 2 (1977): 129-39.

54. Jody Fagan, "Students' Perceptions of Academic Librarians," The Reference Librarian, no. 78 (2002): 131-48.

55. Larry R. Oberg, Mary Kay Schleiter, and Michael Van Houten, "Faculty Perceptions of Librarians at Albion College: Status, Role, Contribution, and Contact," College E Research Libraries 50, no. 2 (1989): 215-30.

56. Gaby Divay, Ada M. Ducas, and Nicole Michaud-Oystryk, "Faculty Perceptions of Librarians at the University of Manitoba," College E Research Libraries 48, no. 1 (1987): 27-35; Robert T. Ivey, "Teaching Faculty Perceptions of Academic Librarians at Memphis State University," College $\mathcal{E}$ Research Libraries, 55, no. 1 (1994): 69-82.

57. On the use of semistructured interviews, field memos, research logs, and member checking in qualitative research, see Robert C. Bogdan and Sara Knopp Biklen, Qualitative Research for Education: An Introduction to Theory and Methods, 3rd ed. (Boston: Allyn \& Bacon, 1998); Strauss and Corbin, Basics of Qualitative Research; and Cresswell, Research Design.

58. Elmborg, "Teaching at the Desk."

59. Walter, "Improving Instruction," 372.

60. Patterson and Howell, "Library User Education," 521-22; Peter Seldin, "Research Findings on Causes of Stress Among Teaching Faculty," in Coping with Faculty Stress, ed. Peter Seldin, 13-21 (San Francisco: Jossey-Bass, 1987).

61. Westbrook, "Passing the Halfway Mark."

62. Oberg, Schleiter, and Van Houten, "Faculty Perceptions of Librarians at Albion College," $220-21$. 
63. Abbott, "Professionalism and the Future of Librarianship"; White, "The Successful Future of the Librarian."

64. Google, "Google Corporate Information," available online at www.google.com/corporate/ [accessed 25 July 2006].

65. On purposive sampling, see Cresswell, Research Design, 185; and Burke Johnson and Larry Christensen, Educational Research: Quantitative, Qualitative, and Mixed Approaches, 2nd ed. (Boston: Allyn \& Bacon, 2004), 215.

66. On data saturation in qualitative research, see Strauss and Corbin, Basics of Qualitative Research; and Greg Guest, Arwen Bunce, and Laura Johnson, "How Many Interviews Are Enough?: An Experiment with Data Saturation and Variability," Field Methods 18, no. 1 (2006): 59-82.

67. Watson-Boone, Constancy and Change in the Worklife of Research University Librarians; White, "The Successful Future of the Librarian." 372 .

68. Patterson and Howell, "Library User Education," 522; Walter, "Improving Instruction,"

69. Walter and Hinchliffe, Instructional Improvement Programs, 12.

70. Lortie, Schoolteacher, 61.

71. Hernon and Pastine, "Student Perceptions of Academic Librarians"; Fagan, "Students' Perceptions of Academic Librarians."

72. W. Lee Hisle, "Top Issues Facing Academic Libraries: A Report of the Focus on the Future Task Force," College \& Research Libraries News 63, no. 10 (2002): 714-15, 730.

73. Martin, "The Accidental Profession."

74. Kenneth Eble, Professors as Teachers (San Francisco: Jossey-Bass).

75. White, "The Successful Future of the Librarian."

76. Alison Cook-Sather, "Unrolling Roles in Techno-Pedagogy: Toward New Forms of Collaboration in Traditional College Settings," Innovative Higher Education 26, no. 2 (2001): 121-39.

77. Gary Rhoades, "The Changing Role of Faculty," in Higher Education in Transition, eds. Joseph Losco and Brian L. Fife, 29-49 (Westport, Conn.: Bergin \& Garvey, 2000).

78. Watson-Boone, Constancy and Change in the Worklife of Research University Librarians, 1.

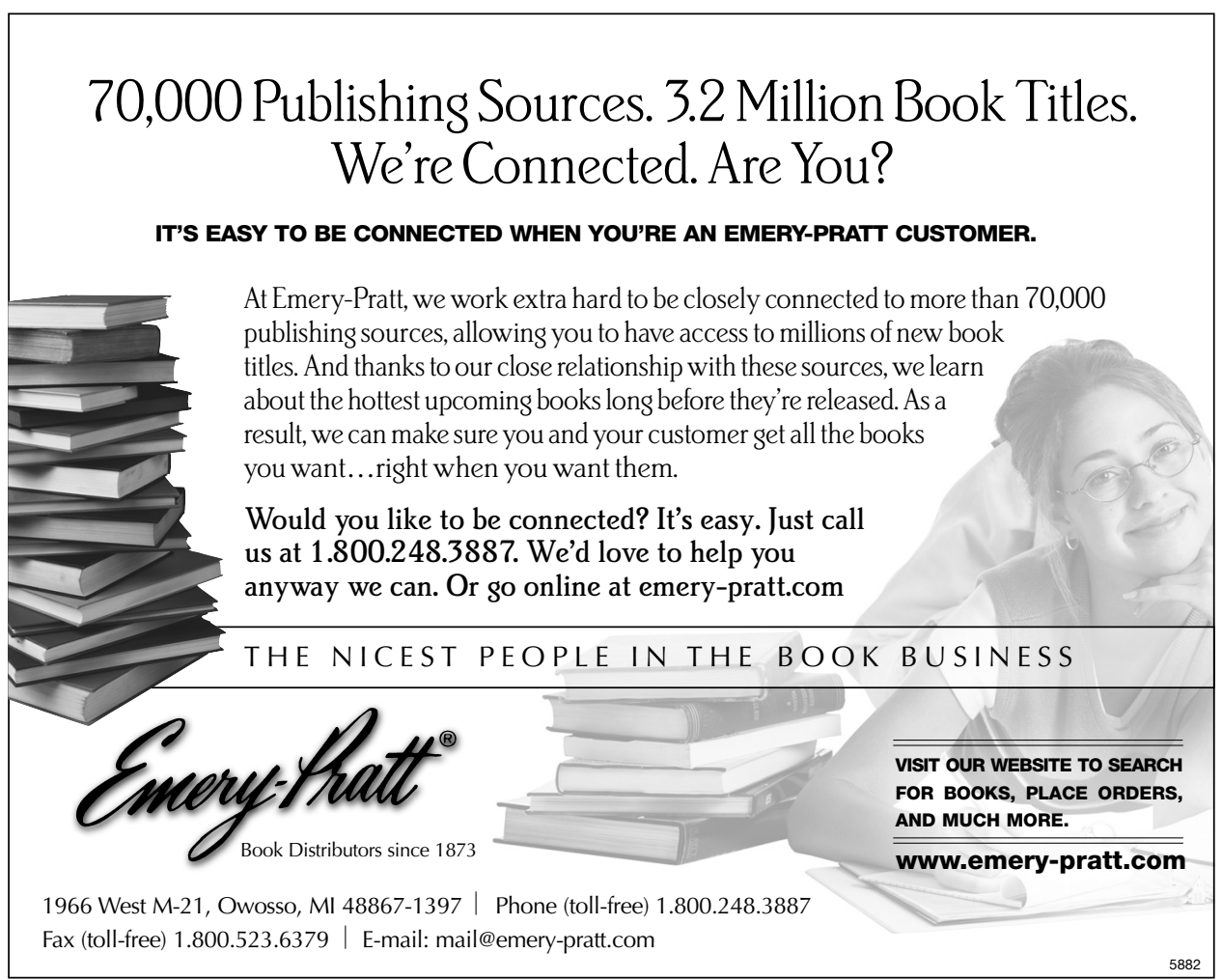


A Qualitative Inquiry into Professional Identity 71

\section{Appendix One Interview Schedule}

1. How long have you been an academic librarian?

2. How did you decide to become a librarian? What drew you to the work?

3. Why did you choose to become an academic librarian?

4. How would you describe your professional work?

5. How do you think it might be described by someone from outside the profession?

6. In what ways do you contribute, as a professional, to the work of the institution?

7. How important are your teaching responsibilities to your work?

8. Can you describe the sort of teaching you do as part of your work?

9. Did you think you would do this much teaching when you decided to become a librarian?

10.When did you learn that teaching was part of what you would be expected to do?

11. What influences have led you to focus on teaching as an important part of your work as a librarian?

12. What excites you about teaching, or, alternately, what troubles you about teaching or your work as a teacher?

13. How have you felt supported (or not supported) in that work and in your commitment to teaching as part of what you do as a librarian?

14. Is there anything else about your work as a teaching librarian that we have not discussed that you would like to talk about? 